engine-room will still have to be quite large. For the auxiliary machinery I will certainly take advantage of superconductivity, so that the wiring of the ship will be cooled by liquid helium ; it must be made of tin or lead wire, since copper is not a superconductor. The magnets in the dynamos will scarcely be different from those already in use.

This suggests a further flight of fancy. My ship on its journeys still has to contend with the resistance of the water. Would it not be more economical to alter the composition of the sea into something less resistant ? If it is liquid helium II, I can economize in many ways. I shall need no special cooling for the superconducting electric wires. I can leave out nine tenths of the ballast, since the density of the sea is now reduced to one tenth. It is possible that I can give up having an engine altogether by giving the ship a good shove at the start of the journey and receiving it on buffers at the end ; I know too little about the real viscosity to judge of this.

But the end of all my plans is tragedy. On account of another of its properties the liquid helium II will irresistibly creep up the sides of the ship, over the bulwarks, across the deck, and down the companion ways, until it settles in the hold, in the effort to come to the same level inside as out. Deeper and deeper will grow the water in the hold, and deeper and deeper the ship will settle, until at last my imaginary ship will founder in the depths of the imaginary ocean.

\section{RESEARCH IN THE NETHERLANDS INDIES*}

By DR. P. HONIG

Netherlands Economic Mission, Washington, D.C.

$\mathrm{R}$ ESEARCH in the Netherlands Indies which tried to improve existing or developing processes was, and is, principally concerned with agriculture in all its aspects. Research in the field of mining had to do with the geological surveys of mechanical engineering as well as metallurgical and civil engineering.

Most of the progress in the Indies has been culled from experience gained in Europe; new scientific aid from Japan, other countries and even from the United States has been of limited significance, except, perhaps, in military matters.

It is not the purpose of this article to discuss medical research, although in the past fifteen years the relation between nutrition, hygiene and the health of the population has been intensified.

Research, as it has been organized in the Netherlands Indies, has to do, primarily, with agriculture and technology. Agriculture includes agrogeology, diseases (phytopathology and entomology) and the methods of planting, selection of varieties, application of fertilizers; the study of technology is directed towards improving the methods of manufacture of agricultural products

The beginning of research work in the Netherlands Indies is seen as far back as the origin of the Botanical Gardens in Buitenzorg some sixty years ago. Without doing injustice to its former directors Teismann and Blume, or to individual explorers such as Rumphius and Junghuhn, the real beginning of systematic

* Substance of an address given at the September meeting of the Society of Netherlands Scientists in the U.S.A. at Cornell University. research began about 1880. Before that time, however, there was a separate survey of the natural wealth of the Netherlands Indies, with the idea of having a detailed summary on minerals, fauna and flora, the geological formations, and the character of natural conditions regarding temperature and weather.

The principle of using science and scientific men to improve existing agricultural industries was first developed in Europe, and it is certain that Germany played a leading part during $1870-1890$ in this matter. Treub, of the same era, was ideal as director of the Botanical Gardens. He worked on the plan of introducing science for practical application, although it was his original contention that most of the scientific research, for application to special plantation crops, must be affiliated with Buitenzorg. $\mathrm{He}$ believed this necessary in order to centralize in one way or another the scientific work; he thought it to be advantageous to move scientific workers about. The idea of centralization was not used, however, by the new "Proef-stations", as the first research centres were called.

The first research centres were organized as private institutions. There were stations for sugar, tobacco, coffee, indigo and for forestry in general. Later, there followed similar centres for tea, rubber, cinchona, palm oil. Then came the Government Agricultural Institute for the study of native crops : rice, copra, cassava, soja, maize and similar produce. The research organizations previous to 1900 employed, in general, phytopathologists; but later agriculturists and biologists, specializing in genetics and physiology, were introduced. In 1930, for example, the total number of workers on the staffs of the Netherlands Indies Governmental and private institutes was 190. These included those working in the fields of agriculture, agricultural industries and technology. All of them were graduates and experts.

At the start, the selection of the research workers was on a broad international base, and most of the European countries sent men of science to work in the Netherlands Indies. This international cooperation was of great benefit to the country. Further, there were the universities in Holland where it was possible to give a limited number of students thorough training. The Netherlands Indies also had the good fortune to have men of science who could read three major foreign languages.

The total number of experts who worked in the Netherlands Indies from 1880 until 1935 was about 850. About 250 of these men had been connected with the Experimental Station for the sugar industry. More than one quarter were foreign residents, while the average time these men were connected with research in the tropics was seven to eight years.

The total number of chemists, agriculturists and biologists engaged in the Netherlands Indies was much greater, however, than the above-mentioned figures. In 1939, there were 250 chemists, of whom 50 were doing research; the others dealt with education, manufacturing processes, consulting agencies and the like. Of the agriculturists, research workers numbered 45 out of 700 in 1939. There were 90 biologists with 25 research workers. The geologists numbered 70, of whom seven were engaged in research. The number of pharmacists was 200, eight of whom were research workers.

Until 1939, the number of Indonesians and Chinese working in science was very small, and the indigenous part of the population provided only five research 
workers. Their contribution to scientific literature was likewise very small.

Following the publication of works on science in the tropics, much controversy arose on 'the creation of new wealth'. It was considered for some time, in effect, that the result of scientific study was the property exclusively of those who were paying the bills. Furthermore, they were secret. On the other hand, it was advocated that for scientific progress it was absolutely necessary that publications should be sent to colleagues working in the same fields in other countries, and that free co-operation be a requirement.

Discussion on these points of view began during 1930-32, years of the severest depression. Companies existing at that time thought that a number of foreign competitors had profited specially by the studies in the Netherlands Indies; that the methods developed in the Indies were only copied when free access had been given to all those who were interested in the results of the research work.

Unfortunately, this discussion had as defender a professor. The rights of the vested interests were defended by a lawyer, who evidently put forth the cause of the financing companies to limit and even to forbid foreign co-operation among the scientific workers. In 1933, the final decision for most of the experimental stations was to drop the open-door policy and to try to keep as secret as possible future results from the laboratories. The steps so taken were undoubtedly bad. Only the worst type of "man of science'- the unreliable and selfish type-saw in this policy of secrecy an opportunity to exploit his own position and his own acumen. In the small, closed communities of manufacturing companies, generally speaking, objective criticism was lacking; and prominence was given those who talked a great deal but said little. The best scientific workers were more or less ignored.

During this unhappy period, the Council for Natural Sciences in the Netherlands Indies made an attempt at a certain amount of co-operation as a counter-measure and, if possible, for the entire Netherlands Kingdom. It did this by an organized exchange of experience between the stations and professors of natural science in Holland, who were acquainted with the problems of the tropics. To this date, however, the matter remains unsettled.

Most of the studies on the Netherlands Indies are published by the stations themselves, usually in the Dutch language, but, where there are large foreign interests, as in the rubber industry, in English as well. The number of technical periodicals distributed throughout the whole world before the War was: engineering, 1 ; medical, 3 ; geological, 1 ; pharmaceutical, 2 ; chemical and technological, 1 ; sugar, 2 ; general agriculture, 3 ; tea, 1 ; rubber, 2 ; cinchona, 1 .

In 1914, periodicals in the Netherlands Indies totalled seventeen. About nine tenths of all the studies in the Netherlands Indies were published in these journals, while one tenth was found in other countries. Before the War, the material was contained in Dutch publications ; at present it is found in American and British periodicals.

Studying research on the Netherlands Indies reveals excellent co-operation with other countries. The share of work done by foreign men of science, among whom may be mentioned Germans, Swedes, Swiss and Russians, is important. The relations between nationalities and scholars of different univer- sities have been of benefit to all. In the past years, selection of scientific workers has become limited and the trend was preferably national. An additional limiting factor was that well-known professors, or high officials, in the Netherlands were used as liaison officers for the selection of young graduates to be sent to the Dutch Colonies.

There appears to have been an unfortunate narrowing of the field from which men are selected in the Netherlands Indies. After the War, it is to be hoped that all men of science interested in the Netherlands Indies, and living and working in other countries, will stimulate their students to go to the Indies for work and study, because working in the tropics can prove an excellent occupation. The number of research workers in the Netherlands Indies, which has been given above, is very small. The United States has at present 70,000 experts working on natural science. In the Netherlands Indies there is a maximum of 300 , partly because some of the findings, especially in connexion with the oil and tin industries, are made in other countries where facilities are better than in the Indies.

The United States at the present time is spending 300 million dollars a year on research. In the Netherlands, three years ago, expenditure amounted to 3 million guilders, which meant that of the exports about one half per cent of export money was used for research. It is generally believed that money used for data on the Netherlands Indies yields profitable returns. In some cases, such funds have had to be increased; but, because of the conditions of prices and quantities of produce to be exported, it is very difficult to stabilize the amount.

It may be expected, however, that the money will be increased eventually. Previous to 1930 , more than 80 per cent of the research work was done by private organizations. The trend now is that much more will be done by Government or by private institutes under Government control. It is also to be expected that after the War the Netherlands Indies will ask for more research workers and that they will be asked to come from widely divergent places. The Netherlands Indies are dependent on foreign sources, not only for the scientific workers themselves but also for equipment and literature. Only laboratory buildings and assistants are available in the Indies.

Many countries are even now considering how this research can be directed, including the Indies, where the Government had founded the Council for Natural Sciences for the Netherlands Indies. This may be compared with the Koninklijke Açademie voor Wetenschappen, which studied and promoted scientific work in the Netherlands Indies. One of the difficulties for a practical organization is that a number of the directors of experimental stations there must be trained to the right responsibility. Their attitude must still be made more active regarding the proper locale for scientific work, and there still is misunderstanding on the part of a financial board. The director of an experimental station must be convinced that he is the one responsible for the work turned out. He must not be passive about defending the rights of the scientific workers and in finding a proper solution for publication policy as well as in stimulating co-operation. In most experimental stations the scientific locale and general set-up do not rise above the scientific and social outlook of their directors.

Considering the specialized science already established, it may be asked : What of the men themselves 
to be selected for the future ? A start was made with chemists, and later biologists and agriculturists arrived, followed by the biochemist.

So, the first step to take after the War is to seek men who are suitable. The specialized research worker is not so important, for too much value has been attached to the title rather than to the man, his experience and qualifications. A 'clan' formation in the scientific world may develop with biologists sticking together and agriculturists training themselves in mutual admiration. It must. be realized that the physicist, as well as the engineer, the biochemist and the technologist are also useful.

In the Netherlands Indies there has always been considerable discussion about pure and applied research. Naturally, there is not a single experimental station which is not interested in fundamental research work, without regard to specific applications of the facts to be discovered. The danger of an experimental station is not that it is doing too much on pure science, but that a research institute has also to act as a consultant.

In certain conditions, this can result in lack of time for real research. The research worker should not be spoken of as an impractical, unsocial, professorial type, with the "zeal and satisfaction of the crusader", in devoting his whole life to science. Perhaps in the past there have been certain of this extraordinary type of man; but those who have been in the Netherlands Indies were no strangers in the economic world, and their outlook upon life was just the same as that of common men with common sense. Most of them, however, had great zeal, with an honest idea of scientific truth and with intelligence above the standard.

The Council for Natural Sciences, which has been studying the scientific future for the past two years, will play a leading part in choosing intelligent and zealous men of science, because it is convinced that governmental encouragement and support of research is a necessity ; that the best form for this encouragement is to provide sufficient assistance to existing associations; and that all research should not be handled by a centralized governmental service. Decentralization of research, with boards interested in the problems to be studied, is the future development to be desired. Further, the funds for research must be increased.

It should also be possible in the future to criticize frankly research in certain industries. The Netherlands cinchona industry, for example, which had been a profitable one, was only using pharmacists and keeping secret everything which they were doing. According to the general feeling of a great number of men of science, however, insufficient research on the details of bark composition, quinine chemistry and manufacture of substitutes was being done; the industry felt that it was in a safe corner with its secrecy and profits ; but a world with more freedom is the goal, and such secrecy is unpalatable.

An important factor for the future of the Netherlands Indies is that it has decided to create a complete university, with courses in all the natural.sciences, to be maintained on the same level as the Dutch universities. Such a university would be an important centre of research in the future. The problems of society vis-d-vis science in the Netherlands Indies are not confined to this country. They are general world problems. We must do away with the secrecy impressed upon men of science by their employers. Open discussion is the best for the enlightenment of business executives, and it must be made possible for every man to discuss his work and aims. The post-war scientific world in the Indies must have workers in a free world who feel they belong to a group which has forgotten all limitations set by frontiers, races and laws-because science is one of the expressions of the higher unity of mankind and the world.

\section{ORIGIN OF MALIGNANT TUMOUR CELLS}

\author{
By Dr. P. C. KOLLER
}

Institute of Genetics, University of Edinburgh

TN the light of recent knowledge of chromosome 1 chemistry and gene action and its bearing on the interpretation of the mitotic cycle in the cell, a cytological analysis was carried out on 565 human tumours (carcinoma of the skin, œsophagus, colon, rectum, larynx, lung, cervix, uterus and breast) ${ }^{\mathbf{1}}$. It was expected that by analysing the characteristics of chromosome and nucleolus behaviour, abnormalities specific to the internal organization of tumour cells might be detected. The present article contains a brief summary of the data obtained ${ }^{2}$.

\section{Nucleolus}

Pianase $^{3}$ had already reported that the nucleolus, a permanent structure in the resting nucleus of cells, is larger in tumours than in normally functioning tissue. His observations have been corroborated since by many investigators. During the last few years cytogenetical research has accumulated experimental proofs that the nucleolus is produced by the so-called 'nucleolar organizers', which are a group of genes located in particular regions of the chromosomes. Nucleoli are formed at the completion of mitosis and their size may increase during the resting stage. They disappear at the beginning of the prophase of the succeeding division. Although there are great differences in the histological structure of tumours of different tissues, the behaviour of the nucleolus is always the same.

It was observed that $(a)$ nucleoli in cells of the same tumour differ in their chemical contents; $(b)$ they are of varying size; and (c) nucleoli in cells of different tumours of the same kind may differ in both, that is, in size and chemical content.

Nucleoli giving Feulgen's positive reaction are known to contain desoxyribose nucleic acid; they usually appear as small, deeply stained granules ( $A$ in accompanying photograph). Such nucleoli represent heterochromatic regions in the chromosome, which retain the nucleic acid charge during the resting stage. In nucleoli which give a Feulgen's negative reaction, on the other hand, desoxyribose nucleic acid is absent, and, as ultra-violet absorption indicates, there is a large amount of protein of the histone type and the ribose form of nucleic acid. These nucleoli are large $(B)$, and they show great variation in size, which is due to the different amount of histone-protein and ribose nucleic acid present.

It is seen that tumours are not homogenieous from a cytological point of view, but are composed of cells with Feulgen's positive and negative nucleoli. 